\title{
NATURE-BASED SOLUTION AS FLOOD PROTECTION STRATEGIES: THE CASE OF CARAHÁ RIVER PARK, BRAZIL
}

\author{
RENATA V. DE OLIVEIRA GOBETTI ${ }^{1}$, ORNELLA SALIMBENE ${ }^{2} \&$ DEBORAH PANEPINTO $^{2}$ \\ ${ }^{1}$ Technological University Dublin, Ireland \\ ${ }^{2}$ Department of Environmental Engineering, Politecnico of Torino, Italy
}

\begin{abstract}
Following the road paradigm, many cities, at the beginning of the 20th century, experienced a reckless increase in the number of vehicles on the road causing an unsustainable urban and environmental situation. The origin of the problem surely lies in the occupation of the preserved areas. In many South American states, for example, highways generally ignore the presence of environmental obstacles (such as rivers) as they may cause a "delay in modernization". As a result, riparian forests are invaded and turned into highways, water beds are channeled and most rivers are contaminated with wastewater. Due to the occupation of green and riparian areas, urban floods have become more and more and consequently urban spaces have been disqualified. This situation also involved the Carahá River that crosses the city of Lages in southern Brazil, in fact the river embankment has become completely impermeable due to the construction of an urban road. Proposing urban spaces with an emphasis on improving environmental quality and integrating forms of public transport are basic points that could lead to the sustainable development of our cities. In this context, the aim of this research is to propose a sustainable river project for the Carahá River, with the aim of presenting nature-based solutions to prevent floods and improve the environmental, functional and aesthetic quality of the city. To develop this research, first theoretical studies were carried out on the relationship between rivers and cities, secondly three international case studies and related literature were analyzed with the aim of deepening the knowledge of the connection between rivers and population. Finally, an intensive study of the territory was carried out and a social analysis was conducted through a semi-structured interview in which the population of Lages participated. The result of this study contributed to effectively defining the intervention guidelines for the Carahá river park project considering, as an added value, also the main needs of citizens.
\end{abstract}

Keywords: river revitalization, flood disaster management, nature-based solutions (NBS), Brazil.

\section{INTRODUCTION}

Nature-based solutions (NBS) are increasingly being adopted as measures to mitigate and adapt to climate change, to reduce flood risks and to improve urban ecosystems [1], [2]. NBS can reduce risks to people and environments as effectively as traditional infrastructure but potentially offer many additional benefits such as the following: improved natural habitat for wildlife, improved water and air quality, improved conditions socio-cultural community [3]. Indeed, over the decades, the occupation of river banks has caused severe flooding and highlighted the enormous lack of proper urban planning of cities in order to avoid these disasters. Some authors have defined the extreme river events as "the revenge of the rivers", highlighting how the race for modernization and strong anthropization, have transformed the life of the people and have profoundly changed the relationship between the city and the river. For example, in the United States, Riley demonstrates that starting in the 1930s, there was no hesitation in channelling the river, digging tunnels or narrowing river beds, and manmade interventions were decidedly invasive. In the same decade, in Brazil, according to Gorsky [4], the river beds were rectified to combat the floods that caused serious epidemics and anthropogenic interventions were justified as a measure of prevention and public health. 
The consequences and environmental impacts generated by these interventions were manifold. Gorski states that uncontrolled and unsustainable anthropization processes expose aquatic life to altered temperatures, increase the speed of water and shut down the biotic components of the system, eliminating its biodiversity.

Furthermore, corrections of river beds cause more erosion and silting, remove aquatic life, damage water quality and alter the hydrological conditions of the river, its drainage capacity, discharge processes and ultimately its flow. In an attempt to alleviate flood problems in some areas, the Carahà river has undergone important changes to its bed over the years. Despite efforts, flooding in specific areas of the city of Lages has become an increasingly frequent problem especially after extreme weather events. To aggravate the problem, also the lack of basic sanitation, in fact in 2010 only $20 \%$ of the wastewater generated in the city was treated, while the rest was discharged into the river (Municipal Water and Hygiene Secretariat (SEMASA)). Observing the precariousness of basic sanitation, the increasing environmental pollution and the disqualification of the river in the urban environment, the main purpose of this work was to develop a landscape redevelopment project based on the NBS (s) to realize a river park and restore the environmental, functional and aesthetic conditions of the banks of the Carahá river.

\section{THEORETICAL RESEARCH}

\subsection{Creating a public space of quality}

According to Lucia Maria [5] to carry out corrections of the riverbed and banks in a river, it is essential to know the characteristics of the site and understand the potential it could offer. It is extremely important to conduct an efficient investigation of land use, hydrology, vegetation, natural drainage and flood prone areas. To intervene and create a high-quality public space around the river, Jacobs [6] listed the following seven strategies to follow: experience (the city as a collective environment), identity and control (feeling of belonging to the space), access to opportunities, imagination and distraction (having new experiences), authenticity and meaning (understanding the collective space), public and community life (encouraging people to public participation), urban self-esteem (urban space is selfsufficient), good environment for all (accessible to all). To achieve these goals, Jacobs states that the urban context should have the following prerequisites:

a) streets and neighborhoods must have an active public life and planning should promote sustainable actions to combat mono-functionality (e.g. not promoting exclusively residential areas) and consequently facilitate the diversity of urban functions (e.g. mixed use);

b) integrate activities (life, work, free time) close to each other, the collective space should be understood as the structuring element of the urban form and not play the role of "excess" space (due to the arrangement of the buildings);

c) avoid or eliminate the concept of urban structures organized according to dispersed and distinct buildings with an excessive complexity of arrangements and relationships in space.

In short, for the construction of a quality public space, it is necessary to attribute to the place a diversity of uses, functions and users. For Jacobs, parks are defined as ephemeral places and when they are successful in the urban context, it means that they have no competition with other green areas. The author further states that if the goal of an urban park is to attract the greatest number of types of people at different times of the day, then it is 
essential to promote a generalization of attendance through the multiplicity of reasons people have for attending the park. For this assumption it is not necessary to have a complex plan of the park but just add some relevant difference or quantity of vegetation that will be accentuated by the different uses in the park. In addition to real river parks, there are alternative drainage systems that reduce the cost of urban infrastructure and also alleviate the problem of flooding. This type of alternative drainage systems are called green infrastructures (GI), an effective example being rain gardens that could be placed near the road curb to receive surface rainwater runoff. Another example is provided by the linear depressions rich in vegetation (earth and other filter elements) which cause the slowing down, the purification of rainwater and increase the runoff time. To adopt a green infrastructure for environmental qualification, the use of native vegetation with high filtering and purifying power is essential. The most effective plants for these purposes are the following: bamboo (bambusa vulgaris), calla (zantedeschia aethiopica), achira (canna edulis) and papyrus (cyperus) [7]. Specifically, the reed bed (phragmites australis) has a rapid growth advantage and has an efficient system of oxygen transport from the leaves to the roots; the water hyacinth (eichhornia crassipes) on the other hand has the ability to absorb heavy metals and organic elements and is able to reduce coliforms and bad smells of polluted water by $77 \%$. Fig. 1 shows the main plants with a purification effect and the main environmental aspects related to them.

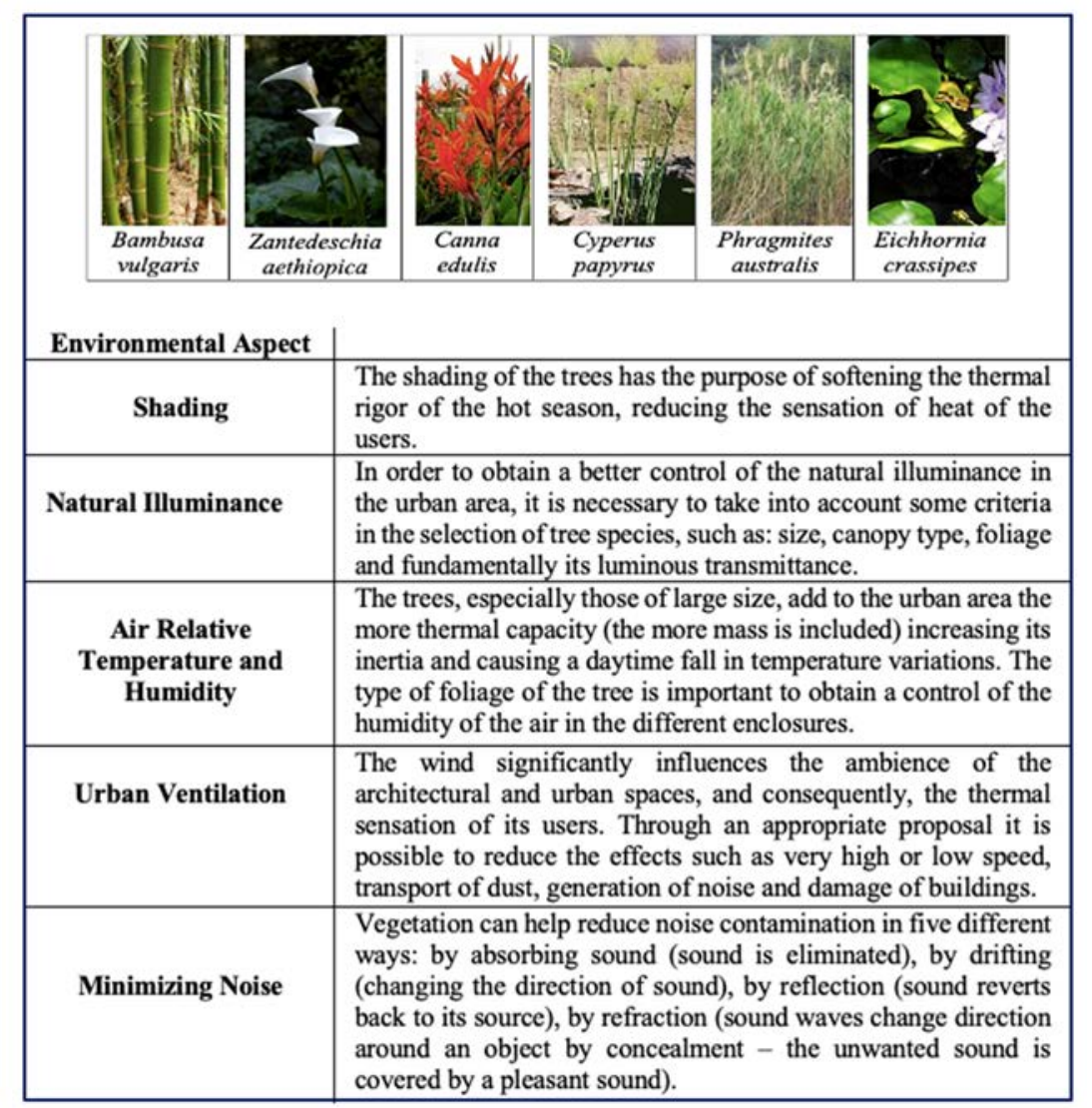

Figure 1: Plants in act in the water treatment and environmental aspect. (Source: Authors.) 


\section{LITERATURE REVIEWES: RELATIONSHIP BETWEEN RIVERS AND CITIES}

\subsection{Los Angeles (California, USA)}

The city of Los Angeles located in California (USA) was developed on the banks of the Los Angeles River. In 1894 the river was rectified and as a result numerous floods began to occur. In 1914, the river was channeled by the United States Army Corps of Engineers. The proposed revitalization of the Los Angeles River only started in 2002 and provided for an intervention cut in the urbanized area of the city corresponding to $59.2 \mathrm{~km}$ of river extension [8]. The intervention was divided into nine sections, defined by specific characteristics, deficiencies and potential. Fig. 2 shows the Los Angeles River before revitalization and the Los Angeles River Project for revitalization.

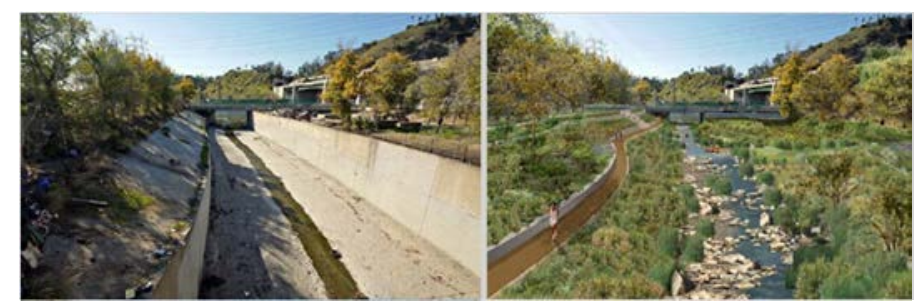

Figure 2: Los Angeles river before revitalization and Los Angeles River Project for revitalization. (Source: Jao, 2014.)

In the early stages, arboreal and herbaceous vegetation was added. Subsequently, the focus was on water depollution and the creation of residential areas. These strategies are mainly aimed at saving the ecological functions of the river, attracting the population and reconnecting communities with each other. For this project, four main objectives have been created and specific guidelines have been developed to achieve the expected result, as seen in Table 1.

\subsection{Cheonggyecheon (South Korea)}

Cheonggyecheon, in Japanese means "clean water", in the past the river was a utility in the daily life of the rural city, it represented the playground for children and laundry for women. In 1958 the river was invaded by the main road which would later become one of the most important urban arteries. In 1999 the municipality started the Cheonggyecheon river recovery project, which involved the demolition of the highway and the construction of a linear park, giving way again to the natural riverbed [9], [10]. The extension of the demolition was 5.4 $\mathrm{km}$ and about $75 \%$ of the demolition material was reused for the construction of the river park, for the construction of four connection points and new bridges, as well as for the rehabilitation of the stream (Fig. 3) which has been recovered and transformed into a linear urban park of $5.8 \mathrm{~km}$ in length, 400 hectares and 80 meters in width.

The main guidelines of the project were to reclaim the Cheonggyecheon River, promote urban renewal by creating a public space for the population, change the growth model of the city through sustainable means of transport in addition to the automobile.

Over the years Seoul has expanded the public transport network and changed the traffic flows that circulate in the city center, so there has been an increase in the number of users 
Table 1: Guidelines for the revitalisation. (Source: Gorski, 2010.)

\begin{tabular}{|l|l|}
\hline Goals & Guidelines \\
\hline $\begin{array}{l}\text { Revitalisation of the } \\
\text { river }\end{array}$ & $\begin{array}{l}\text { To valorise the floodplains with the recovery of riparian } \\
\text { vegetation; restoring ecosystem functionality (restoring } \\
\text { ecological and hydrological functions in the long term); } \\
\text { improve water treatment and quality; secure public access. }\end{array}$ \\
\hline $\begin{array}{l}\text { Creation of green linear } \\
\text { system of connection } \\
\text { between neighborhoods } \\
\text { and the river }\end{array}$ & $\begin{array}{l}\text { Create a continuous green path; connect the neighbourhoods to } \\
\text { the river; expanding public and recreational spaces; connect } \\
\text { the river to the identity of the neighbourhoods; incorporate } \\
\text { elements of public art along the river. }\end{array}$ \\
\hline $\begin{array}{l}\text { Creation of attraction } \\
\text { and opportunities for } \\
\text { the community }\end{array}$ & $\begin{array}{l}\text { Make the river a focus of activities: accessible, safe, healthy, } \\
\text { green and celebratory place; celebrate the river as cultural } \\
\text { heritage; engaging the local population in the process of } \\
\text { building and planning the neighbourhood. }\end{array}$ \\
\hline $\begin{array}{l}\text { Quality of life of the } \\
\text { population }\end{array}$ & $\begin{array}{l}\text { Increase the supply of employment, housing, and commerce; } \\
\text { create an environmentally appropriate urban design and } \\
\text { guidelines and opportunities for land use; concentrate efforts } \\
\text { on the requalification of badly areas and poor communities, in } \\
\text { social disadvantages, guarantee equal access to leisure areas, } \\
\text { work, public transportation, etc.; increase public revenue and } \\
\text { increase income distribution. }\end{array}$ \\
\hline
\end{tabular}
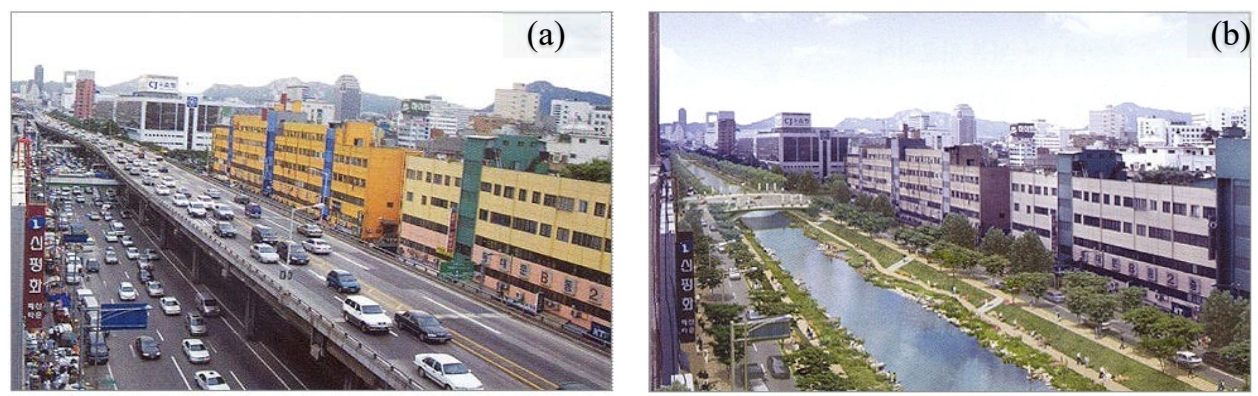

Figure 3: Cheonggyecheon. (a) Before revitalization; and (b) After revitalization. (Source: Giaretta, 2011.)

choosing new transport systems. The project promoted the revitalization of the river space so that citizens could spend more time on the banks of the river. In addition, the reduction in traffic has led to cleaner air and reduced heat islands, with an average temperature $3.6^{\circ} \mathrm{C}$ lower than in other parts of the city. A said consequence of the microclimatic variation has led to the birth of new natural habitats in the city (fish, birds and insects) which have rebalanced some fundamental biological chains. The Cheonggyecheon rehabilitation project has transformed Seoul into a green city with a river of clean and valued waters. One of the main objectives for the development of this project was to transform the city of Seoul into a sustainable city capable of integrating the Cheonggyecheon River into the daily life of the population. However, one of the downsides of revitalization was gentrification and the increase in value from $30 \%$ to $50 \%$ of all properties along the river. 


\subsection{Torino city (Italy)}

In this third case study, the research team of the Polytechnic of Turin examined the water quality of the Po river in a small stretch between two stations (Castiglione Torinese and Brandizzo) in northern Italy (Fig. 4) as a consequence of the polluting loads introduced and the natural ability of the river to receive these loads without critical degradation of water quality. The main objective was to evaluate the effects of the discharge of a purification plant (SMAT) through a qualitative study of water comparing loads, origins, destinations and effects [11]. To achieve these objectives, the hydrological and qualitative picture of the stretch studied was reconstructed using the mass balance method to define the polluting loads in the selected stations and a one-year sampling campaign was carried out. On the basis of the analyzes, it was possible to conclude that the environmental state of the river Po was only minimally influenced by the discharge of the SMAT purification plant and therefore an intervention on diffused loads was necessary (for example, limitation of the use of fertilizer). These results can be useful for river system planners and administrators in the development of future intervention and remediation policies. Furthermore, the proposed methodological approach can be adopted for other significant assessments of the impacts of the polluting load, both from concentrated and diffuse sources.

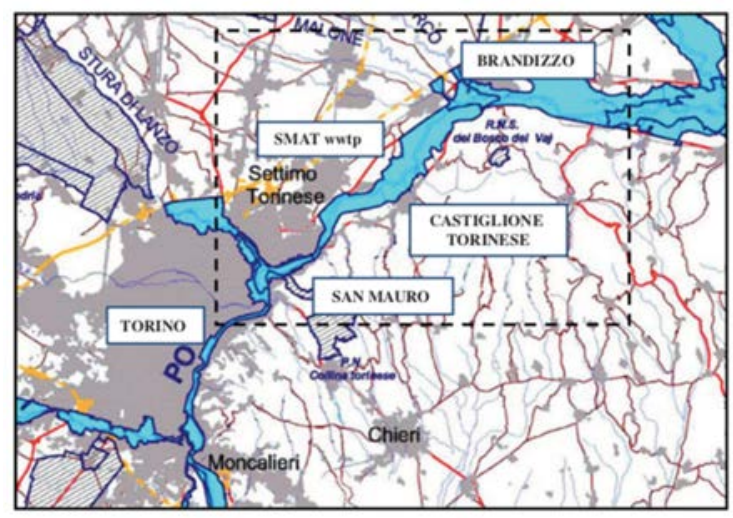

Figure 4: Pò River, main cities and study area (Italy). (Source: Panepinto et al., 2016.)

\section{STUDY AREA: CARAHA RIVER (BRAZIL)}

The city of Lages is located in the mountainous region of the state of Santa Catarina (SC) in southern Brazil and is the largest municipality in the state of SC by territorial extension (Fig. 5(a)). However, the extension of the urban area in the city corresponds to just over $8 \%$ of the total area as shown in the image. The average temperature is $14.3^{\circ} \mathrm{C}$, the predominant wind in the city is the northeast and its annual rainfall is about $1600 \mathrm{~mm}$ with the periods of greatest rainfall in the months of May, June, July and August. Lages is located in the Uruguay watershed, in the Canoas river basin (National Water Agency, 2014), the city is crossed by the Carahá river for $9 \mathrm{~km}$ of extension from start to finish. $83 \%$ of the basin area is sealed and public roads and footpaths account for $35 \%$ of sealed soil in private residential areas contributing to the floods [12]. Fig. 5(b) (1940) shows the beginning of the urban expansion of Lages (highlighted in red) which took place around the cathedral of the city, furthermore the river rectifications are visible. 

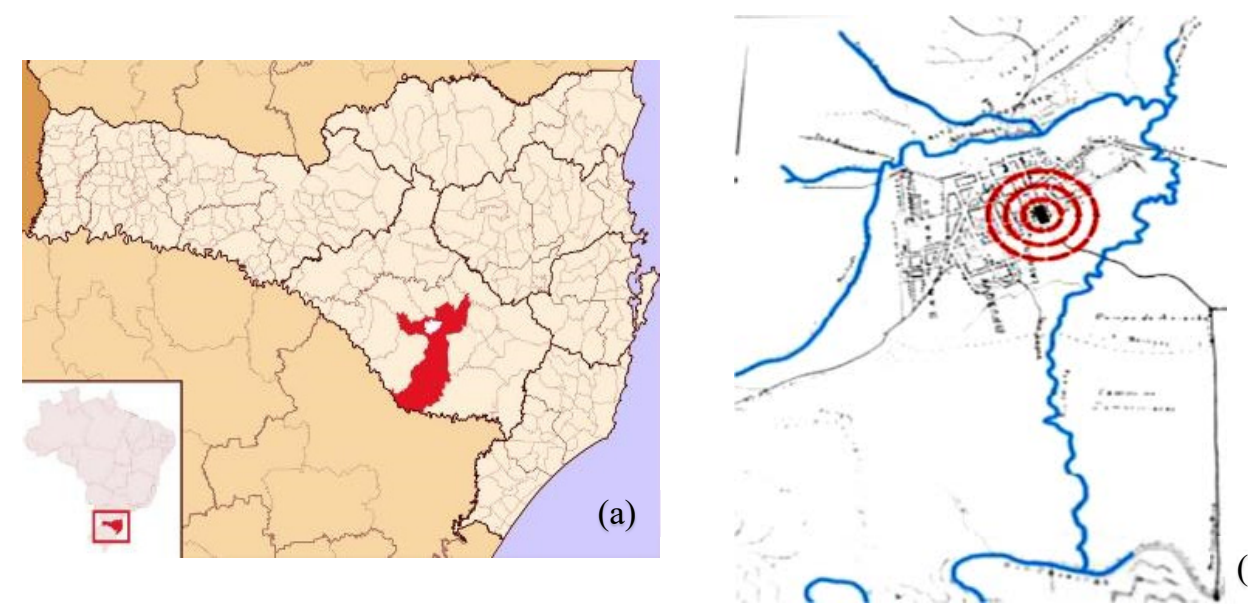

(b)

Figure 5: (a) Lages city. (Source: SIRHESC, 2014); and (b) Caraha River in 1940. (Source: Thiago de Castro Museum.)

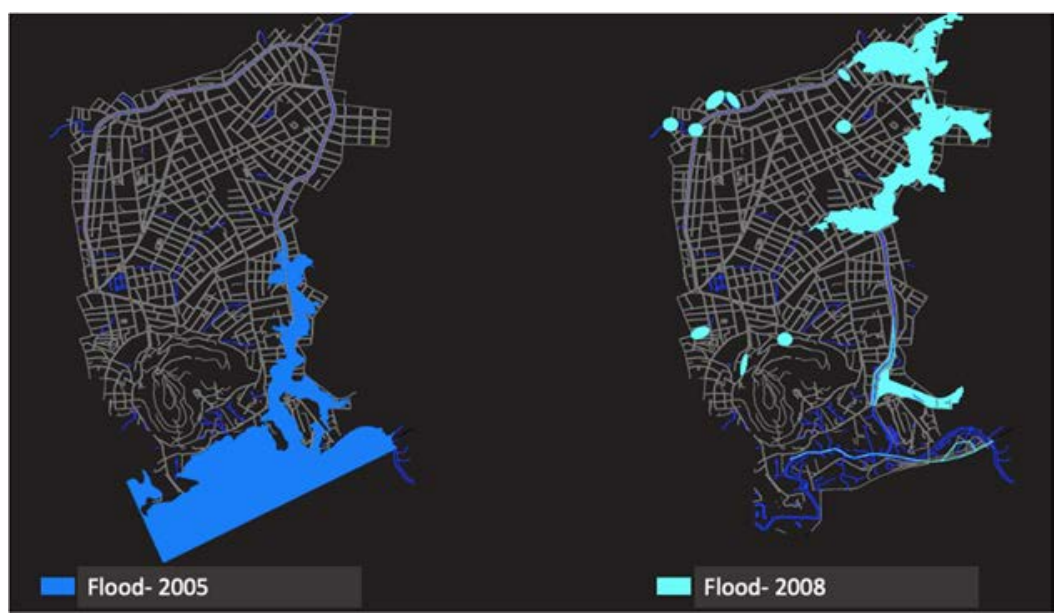

Figure 6: Floodings in 2005 and 2008, consecutively. (Source: SEMASA, 2020.)

According to the data available from the Municipal Secretariat for Water and Lages Hygiene (SEMASA), Fig. 6 represents the areas most affected by the rains of 2005 and 2008.

There are two main reasons according to Palma Neto [13] that cause the flooding of the Carahá river in the city of Lages and they are summarized below:

1) The small ciliary band of the river is limited to $8-10 \mathrm{~m}$ along the river.

2) Inadequate afforestation in the ciliary forest section where there is a low density of large specimens. Furthermore, another factor that causes flooding is the discharge of wastewater directly into the river without any preventive treatment. In Lages, according to the Ministry of Health (2006), only $37.7 \%$ of waste water was collected in 2000 , several studies have also indicated that there are no pristine waterways in the urban 
perimeter of Lages. In 2013, a legislative motion proposed diverting and suppressing sections of the Carahá River to remedy the floods and improve the flow of water, while neglecting the socio-environmental fragility that this intervention would entail. As demonstrated in this work, transforming a river bed into a "concrete box" involves a brutal intervention in nature and does not address the causes of the flood problem. A project called "Carahá de Cara Nova" has been proposed in the city which aims to preserve the river and raise awareness of its importance. Working concurrently with this existing project, the proposed revitalization of the river park aims to raise awareness and enhance the importance of the river for the city and its consequent conservation.

\subsection{Research methodology: Questionnaire}

The citizens of Lages were given a questionnaire to understand the perception of the local population in relation to the public spaces of the city. According to the questionnaire presented to a sample of fifty people of various age groups, $82 \%$ replied that they felt the lack of public spaces in the city of Lages. In fact, despite the great potential for the creation of a river park, the Carahá River has only a still precarious cycle path along its banks. To better organize the questionnaire, The River Carahá, was divided into six sections (Fig. 7) so as to understand which section was the most frequented and used by citizens. Many of the people interviewed confirmed that they do not use some sections of the river bank due to a lack of urban infrastructure: adequate cycle paths, protective embankments, lighting. However, most people who answered the questionnaire confirmed that they use river banks more than three times a week for physical activity (walking, running or cycling).

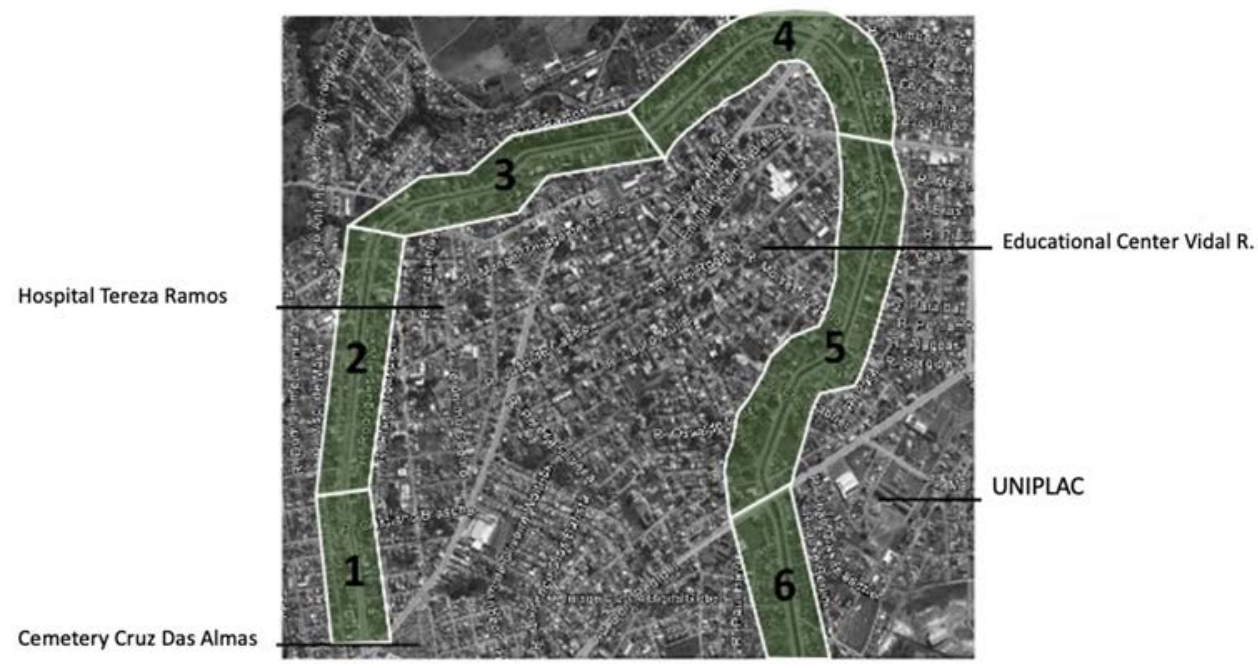

Figure 7: Section of river Carahà. (Source: R.V. de O. Gobetti.)

The graph in Fig. 8 shows the results of the social survey. The results show which equipment is most awaited by the population for the revitalization of the park. Lawn, footpaths, fruit trees cover the highest percentages, from 30 to $40 \%$, resulting in the greatest needs for the local population. Fishing activities, recreational sports services (skateboarding, 


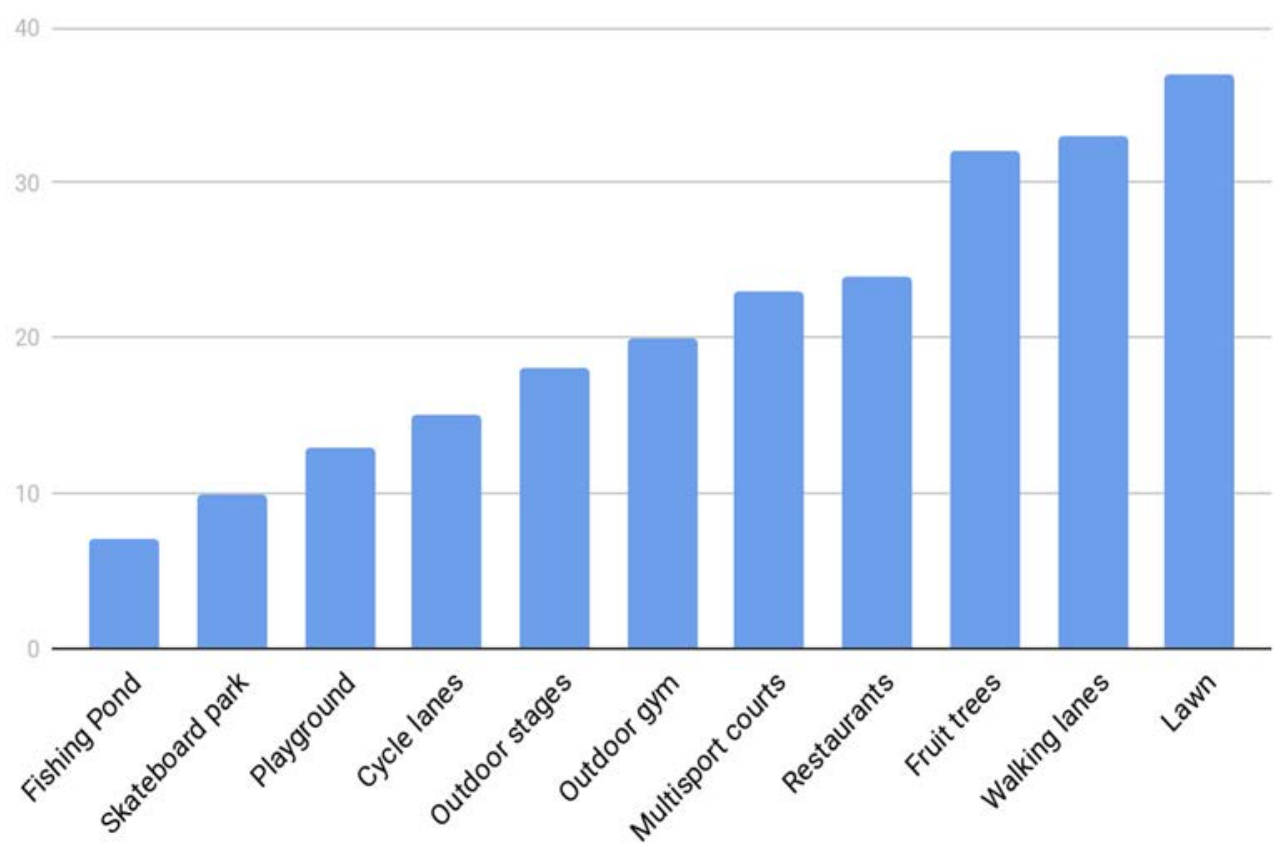

Figure 8: Result of social survey. (Source: R.V de O. Gobetti.)

cycle paths, gym) rank between $8 \%$ and $20 \%$. Finally, catering and recreational activities cover $23 \%$ of the responses, resulting among the greatest needs of the population immediately after lawn, footpaths and fruit trees.

On the basis of this questionnaire and in situ studies, the two areas most affected by floods were chosen as intervention areas and a green infrastructure was proposed as a practical solution. The first area chosen for the redevelopment is located on a more pronounced curve (section 01 in Fig. 9) and is characterized by the congruence of a tributary of the Carahá with inadequate conservation radius. During a technical-environmental analysis that investigates the entire section and the surrounding area, a density of mainly residential buildings was found in this area. Consequently, it is important to intervene on the territory through conservation and development actions of leisure areas for residents. An improvement of the pre-existing recreational space was planned, including in the design the public facilities suggested by the population that participated in the questionnaire. Thanks to its proximity to the city center, the area affected by the redevelopment has a high potential for the provision of services such as bars and restaurants, spaces for hosting events and a market. The second chosen area was completely flooded in 2005 . This was caused by the rectification of the river which caused an increase in the speed of the water flow causing a flood. The area of section 02 is mainly residential with isolated infrastructures such as the municipal school and the church. The potential identified for this area is that of free time, being an area further away from the city center, it lends itself more to recreational activities in nature. The project identified as possible equipment: sports fields, skating, playground, gym and green areas for contemplation. 

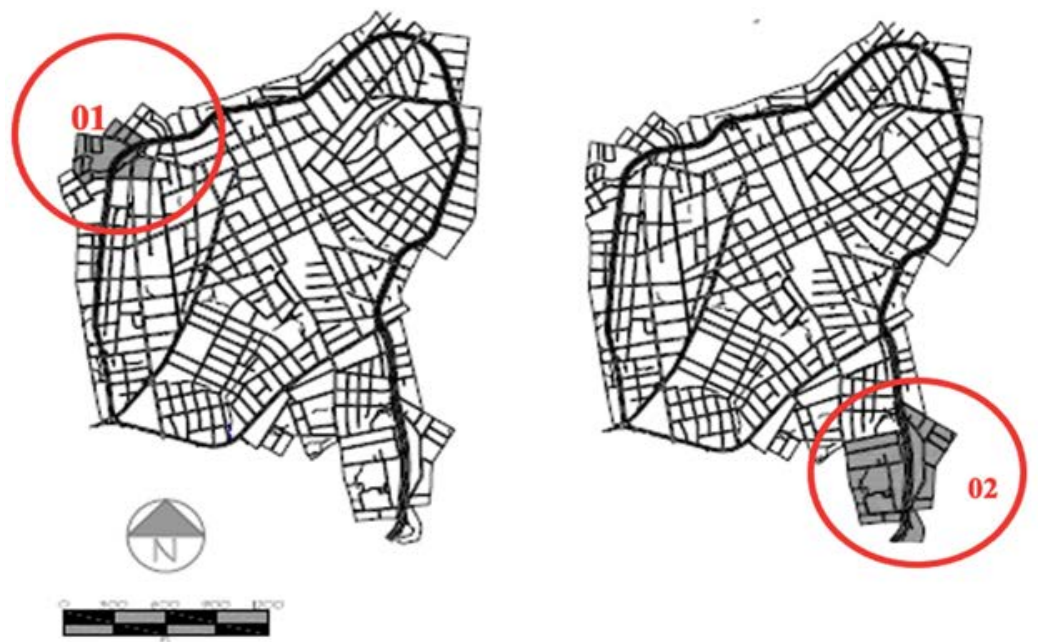

Section Area 01

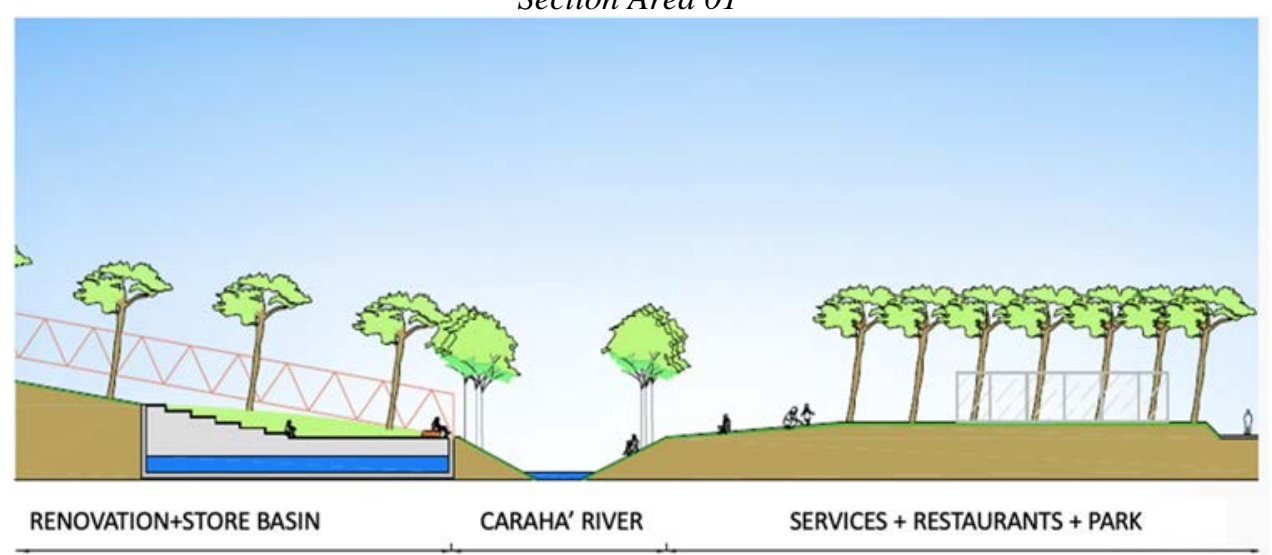

Section Area 02

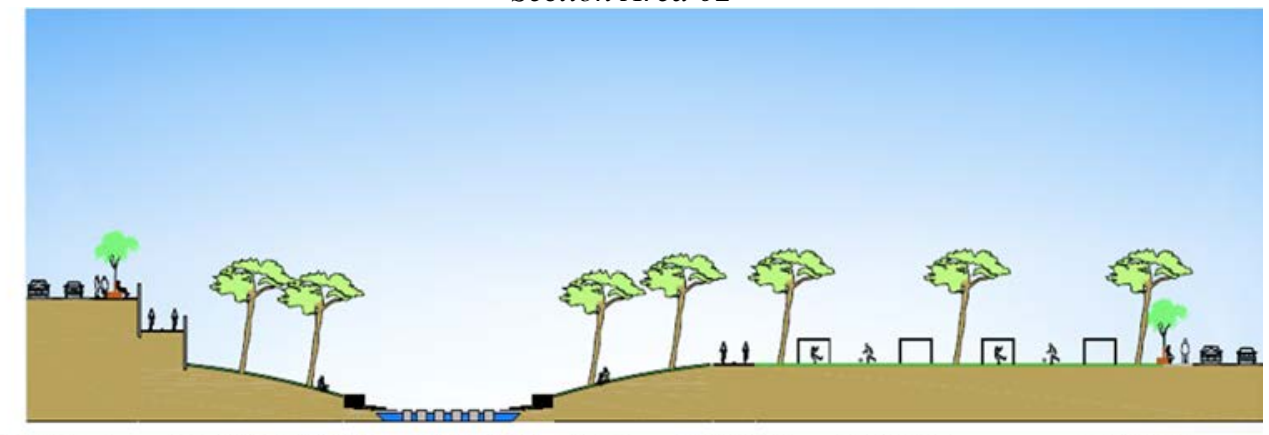

BEUSARIO R. AvenUe + BICYCLE LANE + LEISURE + CARAHA' RIVER + LEISURE + BICYCLE LANE + SPORT AREA + + BEUSARIOR. AvenUE

Figure 9: Intervention areas, section 01 and section 02. (Source: R.V. de O. Gobetti, 2021.) 


\section{CONCLUSION}

The city of Lages has grown considerably over the years and has received significant proposals which need to be well researched before being implemented. The work presented here proposes a preliminary idea of a river park suitable for the prevention of floods and the requalification of the environmental, functional and landscape aspects of the city. For this reason, reference theories and studies were presented that show the impact caused by the canalization and the closure of the river, thus demonstrating that they are not the best solution to adopt [14]. The theoretical review also aims to understand the importance of the river-city connection and to present the direction that urban planning can follow in Brazil in a sustainable way [15]-[17]. To do this, we have exhibited reference studies that are able to reconcile the urban environment with the natural environment and have contributed to the development of guidelines in various aspects. Through a survey on the rains of 2005 and 2008 provided by the Municipality of Lages, areas of flood and low presence of public spaces on the banks of the river were detected, which was the main constraint for the determination of specific areas of the river park. Furthermore, the questionnaire was carried out with people belonging to different age groups, different social classes and dissatisfied with the public spaces existing in the city. However, throughout the study carried out on the territory, it is perceived that the range of influence of public areas often coincides with each other, so this dissatisfaction can be attributed to the lack of existing infrastructures. So that this does not happen again in the planned proposals, the questionnaire also elaborated a program related to the needs of the citizens. In general, the purpose of the Carahá River Park proposal was to include two basic approaches: that of a circuit (Av. Belisário Ramos) offering well-structured cycle paths and tree-lined streets and secondly green recreational spaces. Green areas should have two specific objectives, namely, to represent an NBS that can contain river floods and also meet the recreational needs of citizens. The creation of a river park structured in this way would allow to offer citizens various opportunities and would develop an integrated connection plan between citizens and the river which is the basis of a river regeneration program.

\section{ACKNOWLEDGEMENT}

Thanks to Prof. Me. Arq. Gabriela Morais Pereira, Universidade do Estado de Santa Caterina, UDESC (Brazil) for data support and for supervision of the project work.

\section{REFERENCES}

[1] Cohen-Shacham, E., Janzen, C., Maginnis, S. \& Walters, G., Nature-based Solutions to address global societal challenges. IUCN publication, 2016.

[2] Benjamin D. et al., Natural Assurance Scheme: A level playing field framework for Green-Grey infrastructure development. Environmental Research Journal, 2017.

[3] Dong, X. et al., Enhancing future resilience in urban drainage system: Green versus grey infrastructure. Water Research, 124, 2017.

[4] Gorsky, D. et al., The effects of smolt stocking strategies on migratory path selection of Adult Atlantic Salmon in the Penobscot River, Maine. North American Journal of Fisheries Management, 2011.

[5] Lucia Maria, S.A. et al., Environmental restoration of urban rivers in the metropolitan region of Rio de Janeiro, Brazil. EUE. Environment Urban Journal, 4, 2010.

[6] Jacobs, D. E. et al., Linking public health, housing, and indoor environmental policy: successes and challenges at local and federal agencies in the United States. Environmental Health Perspectives, 115(6), 2007. 
[7] Zanella, L. Plantas ornamentais no pós-tratamento de efluentes sanitários: Wetlands construídos utilizando brita e bambu como suporte. Campinas, São Paulo. 2008.

[8] Jao, C. Feds Okay \$1-Billion Los Angeles River Project. https://www.kcet.org/shows/earth-focus/feds-okay-1-billion-los-angeles-riverproject. 2014. Accessed on: 20 Jul. 2020.

[9] Rowe, P. G. Os resultados e a história do projeto de restauração do Cheonggyecheon, em Seul. AU. (Revista online). Ed 234, set 2013. http://au.pini.com.br/arquiteturaurba'nismo/234/restauracao-do-cheonggyecheon-seul-coreia-do-sul-296126-1.aspx. Accessed on: 16 Apr. 2014.

[10] Giaretta, R. (2011). Uma impressionante renovação urbana em Seul. http://portalarquitetonico.com.br/uma-impressionante-renovacao-urbana-em-seul. 2014. Accessed on: 16 Apr. 2014.

[11] Panepinto, P., Marchese, F. \& Genon, G., Evaluation of Po River water quality in Torino (Italy): Effects of diffuse and local point loads. Urban Water Journal, 13(6), pp. 583-599. 2016. DOI: 10.1080/1573062X.2015.1011669.

[12] SIRHESC. Portal de informações sobre o Sistema de Informações sobre Recursos Hídricos do Estado de Santa Catarina. Bacia do Rio Canoas, 2014. http://www.sirhesc.sds.sc.gov.br/sirhsc/conteudo_upload/316/Estado+canoas.JPG.

[13] Palma Neto, C. Diagnóstico socioambiental da bacia hidrográfica do rio Carahá. 2013.

[14] Fondation Espace Pour La Vie. Capturing water, cooling the air: Rain gardens, 2020. https://fondationespacepourlavie.ca/en/solutions/capturing-water-cooling-the-air raingardens/.

[15] Cometti, J. L.S. et al., Qualidade da água e perspectivas de revitalização de um riacho urbano no Recife, Brasil, RICA, vol. 11. 2020.

[16] Gorski, M. C. B. Rios e cidades: ruptura e reconciliação. São Paulo: Editora Senac. 2010.

[17] Solomon, S. Climate Change 2007-The Physical Science Basis: Working Group I Contribution to the Fourth Assessment Report of the IPCC, Cambridge University Press, 2007. 